Ann. Biol. anim. Bioch. Biophys., 1978, 18 (2 B), 409-417.

\title{
Metabolic and morphological changes produced by gonadotrophins and cyclic AMP in the oocyte and cumulus oophorus of preovulatory rat follicles
}

\author{
by K. AHRÉN, N. DEKEL, L. HAMBERGER, T. HILLENSJÖ, R. HULTBORN, \\ C. MAGNUSSON, A. TSAFRIRI
}

Deportment of Physiology, University of Göteborg, 40033 Göteborg, Sweden.

Summary. LH stimulates the glycolytic activity in the rat ovary and during the periovulatory period marked changes in the follicular energy metabolism occur. This report reviews some data on the respiratory activity of isolated oocytes and cumulus cells near the time of ovulation.

The behaviour of follicle-enclosed oocytes explanted from immature PMSG-treated rats was similar to that of adult proestrus rats. In cultured preovulatory follicles the oocyte remained in the dictyate stage and no changes in cumulus morphology occurred, while exposure to LH brought about oocyte and cumulus maturation in a similar way as in vivo and glucose uptake and lactate formation were stimulated. Cyclic AMP mimicked the LH effect on cumulus maturation and glycolysis but prevented oocyte maturation.

$\mathrm{LH}$ decreased the respiration in isolated cumuli both in vivo and in vitro before any morphological changes occurred.

In isolated oocytes oxygen consumption increased following the resumption of meiosis whether the oocytes were induced to mature by $\mathrm{LH}$ in vivo or matured spontaneously after isolation. Cyclic AMP prevented both maturation and increase in respiration.

The possible relationship between glycolysis and respiratory activity and morphological maturation is discussed as well the role of cyclic AMP in these events.

\section{Introduction.}

Luteinizing hormone $(\mathrm{LH})$ induces the ovulatory process leading to functional and morphological transformation of the mature Graafian follicle into a corpus luteum. This process comprises changes in the steroidogenesis, resumption of oocyte meiosis, morphological transformation of the cumulus oophorus, luteinization of the granulosa cells and eventually follicular rupture and release of the mature ovum. According to current opinion the changes in steroidogenesis and luteinization are mediated by cyclic AMP (review : Kolena and Channing, 1972 ; Marsh, 1976). Much less is, however, known about the role of this nucleotide in the other events of the ovulatory process.

It has long been known that LH can acutely stimulate ovarian carbohydrate metabolism (reviews : Armstrong, 1968 ; Ahrén ef al., 1969), but since this knowledge 
was mainly derived from experiments on whole ovaries and luteinized tissue it has so far been difficult to interpret the hormonal effects in physiological terms. It has recently been found in our laboratories that $\mathrm{LH}$ can stimulate the lactate formation in the isolated preovulatory follicle in vitro (Nilsson, 1974 ; Tsafriri ef al., 1976). Furthermore, following the ovulatory LH surge explanted rat follicles show a markedly increased lactate production. At the same time a decrease of the respiration by isolated cumulus cells occurs (Hillensjö, 1976 ; Dekel et al.,1976). These acute changes in follicular energy metabolism indicate the possibility of a specific role for the $\mathrm{LH}$ effects on ovarian carbohydrate metabolism in relation to the ovulatory process. The mouse oocyte has a specific demand for certain energy substrates for normal development in vitro (Biggers ef al., 1967) and one possiblity could thus be that LH by stimulating follicular glycolysis changes the intrafollicular environment to suit the maturing oocyte. In this report we will review some data from studies on the respiratory activity of isolated oocytes and cumulus cells in relation to the maturational changes prior to ovulation.

\section{Results and comments.}

Characterization of oocyte and cumulus maturation in the PMSG model.

Immature Sprague-Dawley rats were kept under standardized conditions and exposed to light between 0500 and 1900 . When 28 days old the rats were injected s.c. in the morning with $8 \mathrm{IU}$ of PMSG resulting in follicular development with subsequent release of endogenous LH between 1500 and 1800 on day 30, and ovulation of a physiological number of ova in the early morning of day 31 (Fuxe ef al., 1972 ; Hillensjö et al., 1974 ; Herlitz et al., 1976). Oocytes isolated from preovulatory follicles and examined by Nomarski interference contrast microscopy (Tsafriri and Kraicer, 1972) were found to have resumed meiosis after the endogenous LH surge (fig. 1 , left panel). About 50 p. 100 of the oocytes examined at 1900 day 30 showed germinal vesicle breakdown (GVB) and about 50 p. 100 of the oocytes examined at 2400 day 30 had expelled the first polar body (PB). The time-course of oocyte maturation in this PMSG model is thus in principle similar to that seen in the adult proestrus rat (Ayalon ef al., 1972 ; Tsafriri and Kraicer, 1972 ; Vermeiden and Zeilmaker, 1974). The struc-
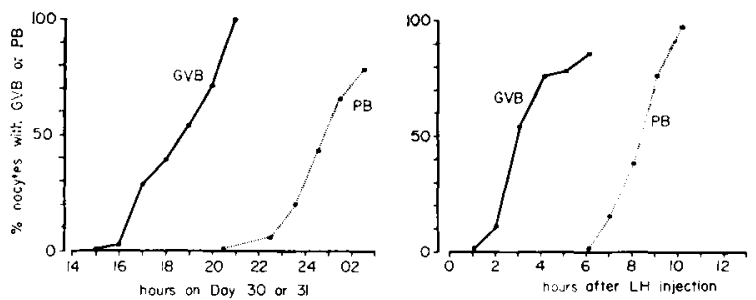

FIG. 1. - Oocyte maturation after PMSG treatment (left panel) or $L H$ injection (right panel). Rats were given 8 IU PMSG s. c. when 28 days old. Oocytes were isolated from large preovulatory follicles at the indicated intervals thereafter either without further treatment (left panel) or after Nembutal treatment $(30 \mathrm{mg} / \mathrm{kg} \mathrm{b.} \mathrm{w.} \mathrm{i.} \mathrm{p.)} \mathrm{and} \mathrm{injection} \mathrm{of} 10 \mu \mathrm{g} \mathrm{NIH}-\mathrm{LH}-\mathrm{S} 18$ i. p. at $1400 \mathrm{hrs}$ day 30 (Data from Hillensjö, 1976 and Magnusson et al., 1977). 
ture of the cumulus oophorus isolated before the LH surge was compact, consisting of densely packed cells, and there was no lysing effect of hyaluronidase. Following the LH surge the cumulus gradually changed into a dispersed structure of cells embedded in a hyaluronidase-sensitive matrix (fig. 2). The changes in cumulus morphology and sensitivity to hyaluronidase, here referred to as cumulus maturation, started somewhat later than oocyte maturation. These results are in agreement with a more detailed chronological analysis of the maturational changes in the cumulus of the adult proestrus rat (Dekel and Kraicer, 1974 ; Dekel et al., 1977).

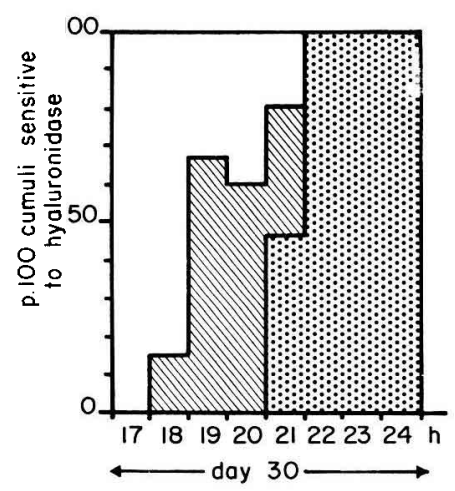

FIG. 2. - Effect of hyaluronidase on cumuli oophori isolated at different time intervals after the endogenous LH-surge. The cumuli were exposed to bovine testicular hyaluronidase $(800 \mathrm{lU} / \mathrm{ml})$ and observed for 3-5 minutes in a stereomicroscope $(\times 40)$. The open part of the bars represent the proportion cumuli insensitive to hyaluronidase, the hatched part represent cumuli partially sensitive and the dotted part cumuli completely sensitive to hyaluronidase. (Data from Hillensjö ef al., 1976.)

Since the exact time for the endogenous LH surge was impossible to predict in the individual animal, the following treatment was chosen in experiments concerned with respirometry of isolated periovulatory cells : the rats were given Nembutal to block the endogenous LH surge and injected with $10 \mu \mathrm{g}$ ovine LH ip between 1400 and 1500 on day 30. As can be seen in figure 1, right panel, about 50 p. 100 of the oocytes examined $3 \mathrm{~h}$ after the $\mathrm{LH}$ injection showed GVB and about 50 p. 100 examined at $9 \mathrm{~h}$ had formed the PB. Cumulus maturation occurred analogously to that described above.

Studies on isolated preovulatory follicles.

Experiments on cultured follicles of proestrus rats showed that the follicle-enclosed oocyte remained in the dictyate stage throughout a 12-24 $\mathrm{h}$ culture period in the absence of hormone, whereas addition of gonadotrophin to the culture medium induced meiosis (Tsafriri et al., 1972 ; Lindner ef al., 1974). Also when preovulatory follicles of the PMSG model were incubated in a chemically defined medium (modified bicarbonate buffer with glucose and albumin) for 2-10 h the follicle-enclosed oocytes remained immature and the cumulus preserved its compact structure, while, on addition of gonadotrophins to the medium, oocyte and cumulus maturation occurred similarly as seen in vivo (Hillensjö, 1976 ; Hillensjö ef al., 1976). Under the same 
conditions LH markedly stimulated glucose uptake and lactate formation by the follicles (fig. 3). Dibutyryl-cyclic AMP (dbcAMP) mimicked the effect of LH on cumulus maturation (Hillensjö, 1977), and follicular lactate formation (fig. 3), but as long as the

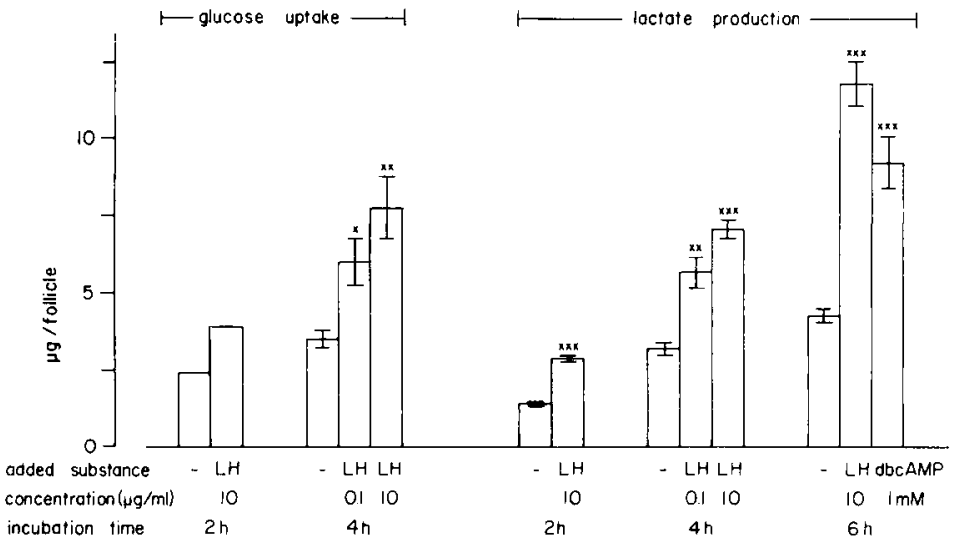

FIG. 3. - Effect of $L H$ on glucose uptake and lactate production and of dibutyryl-cyclic AMP on lactate production of the preovulatory follicle. The follicles were isolated early on day 30 and incubated, 15-20 follicles per flask, in albumin-containing (1 p. 100) modified Krebs-Ringer bicarbonate buffer with $5.5 \mathrm{mM}$ glucose in absence or presence of LH $(\mathrm{N} / \mathrm{H}-\mathrm{LH}-\mathrm{S} 1810 \mu \mathrm{g} / \mathrm{ml})$. After incubation the medium glucose and lactate content was analysed enzymatically. Lactate was determined according to Lundholm ef al., 1963a, b. Glucose uptake was calculated from the difference in medium content before and after the incubation (Hillensjö, 1976). Statistical significance of differences was tested by analysis of variance followed by Student-Newman-Keul's multiplerange test (Woolf, 1968). $x: p<0.05, x x: p<0.01$ and $x x x: p<0.001$ vs control.

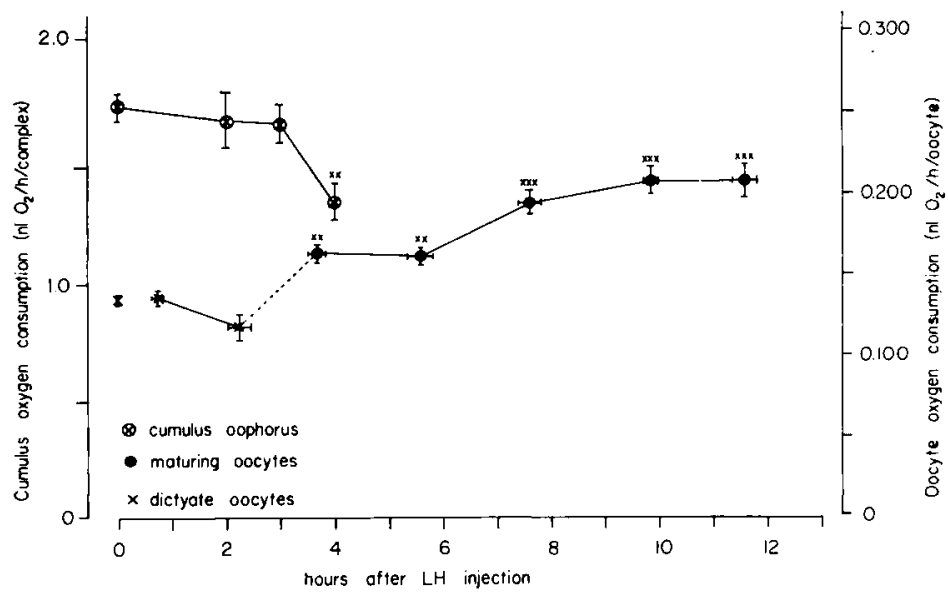

FIG. 4. - Oxygen consumption by isolated cumuli oophori (upper curve) and isolated oocytes (lower curve) after injection of $10 \mu \mathrm{g} \mathrm{NIH-LH-S18} \mathrm{i.} \mathrm{p.} \mathrm{to} \mathrm{Nembutal} \mathrm{treated}(30 \mathrm{mg} / \mathrm{kg} \mathrm{b.} \mathrm{w.} \mathrm{i.} \mathrm{p.)} 30$ days old rats. The rats were treated with 8 IU PMSG s. c. when 28 days old. Cumuli were isolated by puncture of large preovulatory follicles and oocytes were mechanically denuded. The tissue was placed in modified Brinster's phosphate buffered medium, BMOC (Mills and Brinster, 1967 ; Magnusson ef al., 1977) and respiration measured by the microspectrophotometric method (Hultborn, 1974) (Data from Magnusson ef al., 1977 and Magnusson and Hillensjö, unpublished data.) 
nucleotide was present it prevented oocyte maturation. Preincubation of the follicles in dbcAMP followed by transfer to plain control medium, however, enabled oocyte maturation (Hillensjö, ef al., 1977).

\section{Oxygen consumption by isolated cumuli.}

In a previous study LH was shown to acutely decrease the oxygen uptake by the preovulatory cumulus (Dekel, et al., 1976). In further analysis of this effect it was found that cumuli isolated after i.p. injection of $10 \mu \mathrm{g} \mathrm{LH}$ showed a significant decrease occurring $4 \mathrm{~h}$ after the injection (fig. 4). Oxygen consumption was measured by a microspectrophotometric method using hemoglobin as an indicator of oxygen tension (Hultborn, 1974), and the incubation medium was a modified phosphate culture medium (Mills and Brinster, 1967 ; Magnusson et al., 1977). Thus the inhibitory effect of LH on cumulus respiration showed a lag-phase just as did the morphological changes after the exposure to hormone. Also when LH was added to cumuli in vitro for various periods of time there was a decrease in respiration showing that $\mathrm{LH}$ acts directly upon these cells. This decrease, however, developed much more rapidly than in vivo, and a new steady state respiration, amounting to approximately 50 p. 100 of the control respiration, was found already after one hour of culture. By this time there was yet no morphological signs of LH action in the cumulus (Magnusson and Hillensjö, unpublished results). FSH but not prolactin also decreased cumulus cell respiration in vitro (Magnusson and Hillensjö, unpublished results).

\section{Oxygen consumption by isolated oocytes.}

In a preliminary study the oxygen consumption by mechanically denuded oocytes obtained from antral rat follicles was analysed by the micro-diver technique (Hillensjö, et al., 1975). Certain energy substrates which are known to support mouse oocyte maturation in vitro, such as pyruvate and oxaloacetate (Biggers ef al., 1967), when added to the incubation medium increased the oocyle respiration (fig. 5). It was therefore of interest to investigate the oocyte oxygen consumption in relation to the resumption of meiosis.

When oocytes were induced to mature in vivo by $\mathrm{LH}$, the oxygen consumption of isolated and denuded oocytes increased as compared to oocytes in the dictyate stage (fig. 4). In these studies performed with the microspectrophotometric technique, the variation between oocytes within the same experimental group was small allowing a detailed analysis. An increase in oxygen consumption was observed after GVB 3 to $4 \mathrm{~h}$ after the $\mathrm{LH}$ injection. The respiration then gradually increased to maximal values seen in the oocytes with PB.

When the oocytes were induced to mature spontaneously by culture in the medium containing pyruvate, a similar rise in oxygen consumption was found (fig. 6). In this case no hormone was present and the observed rise in respiration must thus be a consequence of the nuclear activation rather than due to a direct hormonal control of the oocyte metabolism. This assumption is supported by the finding that CAMP and dbcAMP, which prevented the spontaneous maturation also prevented the rise in oxygen consumption normally induced by culture (fig. 6). 


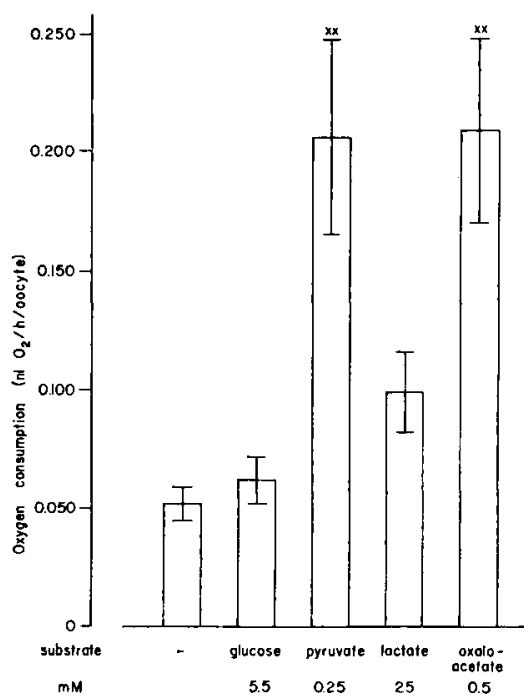

FIG. 5. - Oxygen consumption by isolated oocytes in the presence of different substrates measured by the micro-diver fechnique (Hamberger et al., 1971). Mechanically denuded oocytes obtained from 27-32 days old rats were incubated in Tris- $\mathrm{HCl}$ buffer $\mathrm{pH}$ 7.4. Statistical significance of differences was tested by analysis of variance followed by Student-Newman-Keul's multiple-range test (Woolf, 1968). $x x: p<0.01$ vs control (Data from Hillensịo et al., 1975.)
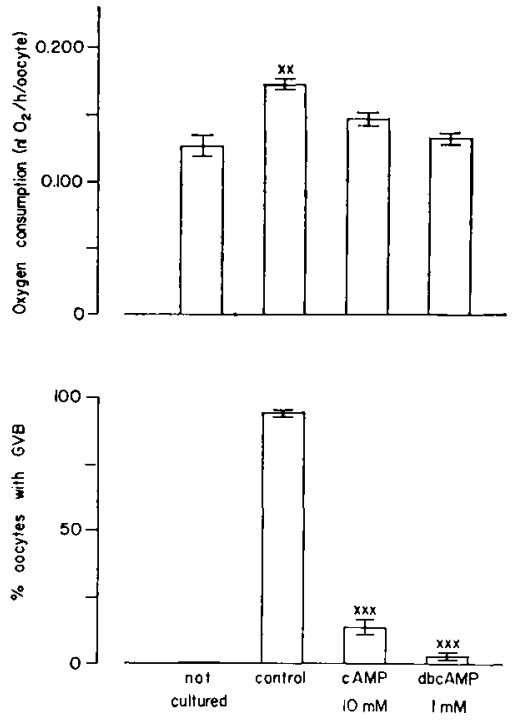

FIG. 6. - Oxygen consumption and maturation of isolated oocyles ofter culture in the presence of cyclic AMP or dibufyryl-cyclic AMP. Cumuli oophori were isolated from 30 days old rats treated with 8 IU PMSG s. c. day 28. They were cultured in modified Brinster's phosphate buffered medium, BMOC (Milis and Brinster, 1967 ; Magnusson ef al., 1977) at $37.5^{\circ} \mathrm{C}$ for $4 \mathrm{hrs}$. The oocytes were then mechanically denuded and placed in plain medium and the respiration was measured by the microspectrophotometric method (Hultborn, 1974) (Data from Magnusson and Hillensjö, 1977.) 


\section{Conclusions and prospects.}

In this series of experiments it was shown that acute changes in the respiratory activity occur in the oocyte and in the cumulus cells in relation to the preovulatory morphological maturation. The preovulatory cumulus decreased its respiration at about the same time as the oocyte increased its respiration. The metabolic shift in the cumulus cells produced by $\mathrm{LH}$ was evident before any change in the morphology of the cumulus complex was observed. An early step in the LH action on the cumulus is probably generation of cyclic AMP. The morphological changes induced by LH can be mimicked by dbcAMP as well as by phosphodiesterase inhibitors (Dekel and Kraicer, 1977 ; Hillensjö, 1977).

In the oocyte oxygen consumption increased after the onset of nuclear maturation. It is likely that the breakdown of the germinal vesicle (GVB) per se triggers the increase in oocyte respiration and that no direct hormonal control of this metabolic event exists. Cyclic AMP may be involved indirectly in the resumption of oocyte meiosis (Tsafriri, ef al., 1972 ; Hillensjö, et al., 1977) but it does not act as a stimulatory agent directly on the oocyte.

One finding of special interest in this study was that the changes in oxygen consumption by the oocyte and the cumulus respectively developed much more rapidly following artificial release of the cells into culfure - about $1 \mathrm{~h}$ - as compared to the lag-period observed when $\mathrm{LH}$ was given in vivo- about $4 \mathrm{~h}$. These differences in time might reflect that the action of $\mathrm{LH}$ in vivo has to counteract an inhibitory influence, which is rapidly removed by the artificial isolation but which needs a longer time for inactivation in vivo. The presence of a follicular oocyte maturation inhibitor has been shown in several other species (Pincus and Enzmann, 1935 ; Foote and Thibault, 1969 ; Tsafriri and Channing, 1975 ; Gwatkin and Andersen, 1976).

Further studies are needed in order to determine the exact mechanisms involved in the gonadotrophic stimulation of both resumption of meiosis and changes in cumulus respiration.

It is not known at present whether the decrease in cumulus cell respiration is essential for oocyte maturation. It is possible that the decreased respiration reflects a Crabtree-effect related to increased glycolysis making more pyruvate available for the oocyte, as discussed in a previous paper (Magnusson, ef al., 1977). It is also possible that the decreased respiration is due to a specific inhibition by $\mathrm{LH}$ of mitochondrial activity in the cumulus cells. The metabolic adjustment in the cumulus cells would then lead to a higher oxygen availability in the oocyte, which may be of importance for the resumption of oocyte maturation (Zeilmaker, ef al., 1972). Studies are in progress to determine the glycolytic activity in the LH exposed cumulus and to analyse the substrate availability of the oocyte within the follicle under various experimental conditions.

27 e Congrès international des Sciences physiologiques, Symposium " Germ and somatic cell interaction " Paris, 21-23 juillet 1977.

Acknowledgements. - This study was supported by grants from the Swedish Medical Research Council (B76-14X-00027, B76-14X-02873-07), The Ford Foundation (7600082), The Medical Faculty University of Göteborg, and Stiftelsen Handlanden Hjal- 
mar Svenssons Forskningsfond. For the generous supply of gonadotrophins we are indebted to The National Institutes of Health, USA, and for the gift of hyaluronidase we thank Leo Itd., Helsingborg, Sweden.

Résumé. La LH stimule l'activité glycolytique de l'ovaire de rat et pendant la période périovulatoire interviennent des changements importants dans le métabolisme énergétique du follicule. Cette étude analyse un certain nombre de résultats sur l'activité respiratoire des ovocytes isolés et des cellules du cumulus au moment de l'ovulation.

Le comportement des ovocytes intrafolliculaires prélevés sur des rattes immatures, traitées à la PMSG, est semblable à celui observé chez les rattes adultes au proestrus. Dans les follicules préovulatoires en culture, l'ovocyte reste au stade dictyé et aucun changement ne se produit dans la morphologie du cumulus. Si on ajoute de la LH, la maturation de l'ovocyte et du cumulus se produit de la même manière qu'in vivo et la consommation de glucose et la formation de lactate sont stimulées. L'AMPc mime l'action de la LH sur la maturation du cumulus et la glycolyse, mais ne permet pas la maturation de l'ovocyte.

La LH diminue la respiration des cumulus isolés in vivo comme in vifro avant qu'aucune transformation morphologique ne se produise.

Dans les ovocytes isolés la consommation d'oxygène augmente après la reprise de la méïose, que la maturation des ovocytes soit induite par la LH in vivo ou reprenne spontanément in vitro après isolement. L'AMPc empêche la maturation et l'augmentation de la respiration.

Les relations possibles entre la glycolyse et l'activité respiratoire et la maturation morphologique sont discutées, ainsi que le rôle de l'AMPc dans ces événements.

\section{References}

AHRÉN K., HAMBERGER L., RUBINSTEIN L., 1969. Acute in vivo and in vitro effects of gonadotrophins on the metabolism of the rat ovary, 327-354. In : McKERNS K. W, The gonads, Appleton-Centure-Crofts, New York.

ARMSTRONG D. T., 1968. Gonadotrophins, ovarian metabolism, and steroid biosynthesis. Rec. Prog. Horm. Res., 24, 255-319.

AYALON D., TSAFRIRI A., CORDOVA A., HARNELL A., 1972. Serum gonadotrophin levels in proœestrus rats in relation to the resumption of meiosis by the oocytes. J. Reprod. Fert., 31, 51-58.

BIGGERS J. D., WHITTINGHAM D. G., DONAHUE R. P., 1967. The pattern of energy metabolism in the mouse oocyte and zygote. Proc. nat. Acad. Sci., 58, 560-567.

DEKEL N., KRAICER P. F., 1974. Periovulatory changes in the rat cumulus oophorus. Symp. Functional Morphology of the Ovary, Glasgow, Sept. 11-14, 1974 (Abstr.).

DEKEL N., HULTBORN R., HILLENSJÖ T., HAMBERGER L., KRAICER P. F., 1976. Effect of luteinizing hormone on respiration of the preovulatory cumulus oophorus of the rat. Endocrinology, 98, 498-504.

DEKEL N., HILLENSJÖ T., KRAICER P. F., 1977. Maturational effects of gonadotrophins on the cumulus-oocyte complex of the rat (submitted to Biol. Reprod.).

DEKEL N., KRAICER P. F., 1977. LH induction of mucopolysaccharide secretion by rat cumulus oophorus in vitro. Israel J. Med. Sci. (in press).

FOOTE W. D., THIBAULT C., 1969. Recherches expérimentales sur la maturation in vifro des ovocytes de truie et de veau. Ann. Biol. anim. Bioch. Biophys., 9, 329-349.

FUXE K., HOKFELT T., SUNDSTEDT C.-D., AHRÉN K., HAMBERGER L., 1972. Amine furnover changes in the tubero-infundibular dopamine (DA) neurons in immature rats injected with PMS. Neuraendocrinology, 10, 282-300.

GWATKIN R. B. L., ANDERSEN O. F., 1976. Hamster oocyte maturation in vitro : inhibition by follicular components. Life Sci., 19, 527-536.

HAMBERGER L., HAMBERGER A., HERLITZ H., 1971. Methods for metabolic studies on isolated granulosa and theca cells, 41-61. In DICZFALUSI E., In vitro methods in reproductive cell biology, Karolinska Symposia on Research Methods in Reproductive Endocrinology, 3rd symp. 
HERLITZ H., KOCH Y., KHAN M. I., AHRÉN K., 1976. Effect of follicle-stimulating hormone on cyclic AMP levels in young corpora lutea of the rat. Europ. J. Obstet. Gynec. Reprod. Biol., 6/4, 175-179.

HILLENSJÖ T., BARNEA A., NILSSON L., HERLITZ H., AHRÉN K., 1974. Temporal relationship between serum LH levels and oocyte maturation in prepubertal rats injected with pregnant mare's serum gonadotropin. Endocrinology, 95, 1762-1766.

HILLENSJÖ T., HAMBERGER L., AHRÉN K., 1975. Respirafory activity of oocytes isolated from ovarian follicles of the rat. Acta Endocr. (Kbh), 78, 751-759.

HILLENSJÖ T., 1976. Oocyte maturation and glycolysis in isolated preovulatory follicles of PMSinjected immature rats. Acta Endocr. (Kbh), 82, 809-830.

HILLENSJÖ T., DEKEL N., AHRÉN K., 1976. Effects of gonadotrophins on the cumulus oophorus of isolated rat Graafian follicles. Acta physiol. scand., 96, 558-568.

HILLENSJÖ T., 1977. Dissociation of preovulatory maturational events in rat oocytes and cumuli in the presence of dibutyryl cyclic AMP. Acta physiol. scand., 100, 261-263.

HILLENSJÖ T., EKHOLM C., AHRÉN K., 1977. Role of cyclic AMP in oocyle maturation and glycolysis in the preovulatory rat follicle. Acta Endocr. (Kbh) (in press).

HULTBORN R., 1974. A spectrophotometric method for analysis of oxygen consumption in vitro on the microscale. Acta physiol. scand., suppl. 404, 1-47.

KOLENA J., CHANNING C. P., 1972. Stimulatory effecis of LH, FSH and prostaglandins upon cyclic 3', 5'-AMP levels in porcine granulosa cells. Endocrinology, 90, 1543-1550.

LINDNER H. R., TSAFRIRI A., LIEBERMAN M. E., ZOR U., KOCH Y., BAUMINGER S., BARNEA A., 1974. Gonadotrophin action of cultured Graafian follicles : induction of maturation division of the mammalian oocyte and differentiation of the luteal cell. Rec. Prog. Horm. Res., 30, 79-138.

LUNDHOLM L., MOHME-LUNDHOLM E., VAMOS N., 1963a. Lactic acid assay with L(+) lactic acid dehydrogenase from rabbit muscle. Acta physiol. scand., 58, 243-249.

LUNDHOLM L., MOHME-LUNDHOLM E., SVEDMYR N., 1963b. Comparative investigation of methods for determination of lactic acid in blood and tissue extracts. Scand.J. clin. Lab. Invest., 15, 311-316.

MAGNUSSON C., HILLENSJÖ T., 1977. Inhibition of maturation and metabolism in rat oocyles by cyclic AMP. J. Exp. Zool., 201, 139-147.

MAGNUSSON C., HILLENSJÖ T., TSAFRIRI A., HULTBORN R., AHRÉN K., 1977. Oxygen consumption of maturing rat oocytes. Biol. Reprod., 17, 9-15.

MARSH J. M., 1976. The role of cyclic AMP in gonadal steroidogenesis. Biol. Reprod., 14, 30-53.

MILLS R. M., BRINSTER R. L., 1967. Oxygen consumption of preimplantation mouse embryos. Exp. Cell Res., 47, 337-344.

NILSSON L., 1974. Acute effects of gonadotrophins and prosiaglandins on the metabolism of isolated ovarian follicles from PMSG-treated immature rats. Acta Endocr. (Kbh), 77, 540-558.

PINCUS G., ENZMANN E. V., 1935. The comparative behaviour of mammalian eggs in vivo and in vitro. I. The activation of ovarian eggs. J. exp. Med., 62, 665-675.

TSAFRIRI A., KRAICER P. F., 1972. The time sequence of ovum maturation in the rat. J. Reprod. Fert., 29, 387-393.

TSAFRIRI A., LINDNER H. R., ZOR U., LAMPRECHT S. A., 1972. In vitro induction of meiotic division in follicle-enclosed rat oocytes by LH, cyclic AMP and prostaglandin $E_{2}$. J. Reprod. Fert., 31, 39-50.

TSAFRIRI A., CHANNING C. P., 1975. An inhibitory influence of granulosa cells and follicular fluid upon porcine oocyte meiosis in vitro. Endocrinology, 96, 922-927.

TSAFRIRI A., LIEBERMAN M. E., AHRÉN K., LINDNER H. R., 1976. Dissociation between LH-induced aerobic glycolysis and oocyte maturation in cultured Graafian follicles of the rat. Acta Endocr. (Kbh), 83, 151-157.

VERMEIDEN J. P.W., ZEILMAKER G. H., 1974. Relationship between maturation division, ovulation and luteinization in the female rat. Endocrinology, 95, 341-351.

WOOLF C. M., 1968. Principles of Biometry, Ist ed., D. van Nostrand Co. Inc., Princetown.

ZEILMAKER G. H., HULSMANN W. C., WENSINCK F., VERHAMME C., 1972. Oxygen-triggered mouse oocyte maturation in vitro and lactate utilization by mouse oocytes and zygotes. J Reprod. Fert., 29, 151-152. 